\title{
Comparison of the National Research Council-2001 Model with the Dutch System (DVE/OEB) in the Prediction of Nutrient Supply to Dairy Cows from Forages
}

\author{
P. Yu, ${ }^{1}$ D. A. Christensen, and J. J. McKinnon \\ Department of Animal and Poultry Science, University of Saskatchewan, \\ Saskatoon, SK, S7N 5A8, Canada
}

\begin{abstract}
The objective of this study was to compare the DVE/ OEB system $(\mathrm{DVE}=$ truly absorbed protein in the small intestine; OEB = degraded protein balance) and the NRC-2001 model in the prediction of supply of protein to dairy cows from selected forages: alfalfa (Medicago sativa L. cv. Pioneer and Beaver) and timothy (Phleum pratense L. cv. Climax and Joliette). Comparisons were made in terms of 1) ruminally synthesized microbial $\mathrm{CP}, 2$ ) truly absorbed protein in the small intestine, and 3) degraded protein balance. In addition, the effects of variety and cutting stage of the selected forages on the potential nutrient supply to dairy cows were also studied. The results showed that the predicted values from the DVE/OEB system and the NRC-2001 model had significant correlations with high $R(>0.96)$ values. However, using the DVE/OEB system, the overall average microbial protein supply based on available energy was $12 \%$ higher, and the truly absorbed protein in the small intestine was $15 \%$ lower than that predicted by the NRC-2001 model. The difference was also found in the prediction of the degraded protein balances, which was $11 \%$ higher based on data from the NRC-2001 model. These differences are due to considerably different factors used in calculations in the two models, although both are based on similar principles. This indicates that a further refinement is needed for a modern protein evaluation and prediction system. In addition, this study showed that the two alfalfa varieties studied (Pioneer vs. Beaver) had no effect, but cutting stage had a profound influence on ruminally synthesized microbial CP $(93,96,86 \mathrm{~g} / \mathrm{kg}$ DM at stage of early bud, late bud, and early bloom, respectively) and truly absorbed intestinal protein predicted by the DVE/OEB system $(80,79,67 \mathrm{~g} / \mathrm{kg} \mathrm{DM}$ at stage of early bud, late bud, and early bloom, respectively). With timothy, both variety
\end{abstract}

Received August 20, 2002.

Accepted November 22, 2002.

Corresponding author: P. Yu; e-mail: yupe@sask.usask.ca.
(Climax vs. Joliette) and cutting stage had significant impacts on the potential protein supply predicted by both models. The potential protein supply (DVE or MP) to the dairy cow from Climax timothy was higher than that from Joliette timothy (DVE: 46 vs. $32 \mathrm{~g} / \mathrm{kg}$ DM; MP: $61 \mathrm{vs.} 38 \mathrm{~g} / \mathrm{kg} \mathrm{DM}$ ). With increasing stage of cutting, the potential protein supply (DVE or MP) was reduced (DVE: 53, 39, $25 \mathrm{~g} / \mathrm{kg}$ DM; MP: 62, 51, 36 $\mathrm{g} / \mathrm{kg} \mathrm{DM}$ at stage of joint, prebloom head, and full head, respectively).

(Key words: DVE/OEB system, dairy cows, forages, NRC-2001 model, protein evaluation)

Abbreviation key: AECP = Truly absorbed endogenous protein in the small intestine $(\mathrm{g} / \mathrm{kg} \mathrm{DM})(\mathrm{NRC})$, $\mathbf{A M C P}^{\mathbf{D V E}}=$ Truly absorbed rumen synthesized microbial protein in the small intestine $(\mathrm{g} / \mathrm{kg} \mathrm{DM})(\mathrm{DVE} /$ OEB), $\mathbf{A M C P}^{\mathrm{NRC}}=$ Truly absorbed rumen synthesized microbial protein in the small intestine $(\mathrm{g} / \mathrm{kg} \mathrm{DM})$ (NRC), $\mathbf{A R U P}^{\mathbf{D V E}}=$ Truly absorbed bypass feed protein in the small intestine (g/kg DM; DVE/OEB), AR$\mathbf{U P}^{\text {NRC }}=$ Truly absorbed rumen undegraded feed protein in the small intestine ( $\mathrm{g} / \mathrm{kg}$ DM; NRC), Degraded Protein Balance $^{\text {OEB }}=$ Reflects the difference between the potential microbial protein synthesis based on rumen degraded feed CP and that based on energy (rumen fermented OM) available for microbial fermentation in the rumen, calculated as: $\mathrm{MCP}_{\mathrm{RDP}}{ }^{\mathrm{DVE}}$ $\mathrm{MCP}_{\mathrm{FOM}}$ (DVE/OEB), Degraded Protein Balance $^{\text {NRC }}=$ Based on the data from NRC 2001 model, the Degraded Protein Balance ${ }^{\mathrm{NRC}}$ (g/kg DM) reflects the difference between the potential microbial protein synthesis based on ruminally degraded feed CP and that based on energy - TDN available for microbial fermentation in the rumen, calculated as: $\mathrm{RDP}^{\mathrm{NRC}}$ $1.18 \mathrm{MCP}_{\mathrm{TDN}}, \mathbf{D V E}=$ Truly absorbed protein in the small intestine ( $\mathrm{g} / \mathrm{kg} \mathrm{DM}$ ), contributed by 1 ) feed protein escaping rumen degradation $\left(\mathrm{RUP}^{\mathrm{DVE}}\right), 2$ ) microbial protein synthesized in the rumen $\left(\mathrm{MCP}_{\mathrm{FOM}}\right)$, and 3) a correction for endogenous protein losses in the digestive tract (ENDP; DVE/OEB), ECP = Rumen endogenous crude protein ( $/ \mathrm{kg}$ DM; NRC), ENDP = Endogenous protein losses in the digestive tract $(\mathrm{g} / \mathrm{kg}$ 
DM; DVE/OEB), $\mathbf{M C P}_{\text {FoM }}=$ Microbial protein synthesized in the rumen based on available energy $(\mathrm{g} / \mathrm{kg}$ DM; DVE/OEB), $\mathbf{M C P}^{\text {NRC }}$ = Ruminally synthesized microbial CP $(\mathrm{g} / \mathrm{kg} \mathrm{DM})$, calculated as $0.130 \times \mathrm{TDN}$, when $\mathrm{RDP}^{\mathrm{NRC}}$ exceeds $1.18 \times \mathrm{TDN}$-predicted $\mathrm{MCP}$ $\left(\mathrm{MCP}_{\mathrm{TDN}}\right)$. When $\mathrm{RDP}^{\mathrm{NRC}}$ is less than $1.18 \times \mathrm{TDN}-$ predicted $\mathrm{MCP}\left(\mathrm{MCP}_{\mathrm{TDN}}\right)$, then $\mathrm{MCP}$ is calculated as 0.85 of $\mathrm{RDP}^{\mathrm{NRC}}\left(\mathrm{MCP}_{\mathrm{RDP}} ; \mathrm{NRC}\right), \mathbf{M C P}_{\mathbf{R D P}}{ }^{\mathrm{DVE}}=$ Microbial protein synthesized in the rumen based on rumen degraded feed crude protein, calculated as: $\mathrm{CP} \times(1-$ $1.11 \%$ RUP/100) (g/kg DM; DVE/OEB), $\mathbf{M C P}_{\mathbf{R D P}}{ }^{\mathbf{N R C}}=$ Microbial protein synthesized in the rumen based on available protein, calculated as 0.85 of $\mathrm{RDP}^{\mathrm{NRC}}(\mathrm{g} / \mathrm{kg}$ DM; NRC), $\mathbf{M C P}_{\text {TDN }}=$ Microbial protein synthesized in the rumen based on available energy (discounted TDN; NRC), MP = Metabolizable protein (g/kg DM) (defined as the true protein that is digested postruminally and the component amino acid absorbed by the intestine) contributed by 1) ruminally undegraded feed $\mathrm{CP}, 2$ ) ruminally synthesized microbial $\mathrm{CP}$, and 3) endogenous CP $($ NRC), TPSI = True protein supplied to the small intestine $(\mathrm{g} / \mathrm{kg} \mathrm{DM})$.

\section{INTRODUCTION}

Most mammals can only metabolize dietary protein as amino acids or peptides absorbed from the small intestine. In ruminants, the relationship is somewhat more complicated. As such, sophisticated models have been developed for dairy cows, such as PDI (INRA, 1978; Verite and Geay, 1987), ARC (1984), NJK-NJF (1985), AAT-PVB (Madsen, 1985), AP (NRC, 1985), ADPLS and MF (Varhegyi et al., 1998). Based on principles in existing protein evaluation systems, modern protein evaluation systems: the Dutch DVE/OEB system (Tamminga et al., 1994) and NRC-2001 dairy model (NRC, 2001) have been developed. These two models consider the strong elements of other recently developed protein evaluation systems, and they also introduce new elements, such as the role of energy balance in intestinal protein supply.

In the DVE/OEB system, the protein value for feeds and the requirements for dairy cows are both expressed as the amount of protein (microbial and feed source) truly digested in and absorbed from the small intestine of the animal. This system can give information on the quantitative aspects of both ruminal and postruminal protein digestion in ruminants. In the DVE/OEB system, each feed has a DVE value, which stands for true absorbable protein in the small intestine, composed of: 1) digestible feed true protein escaping rumen degradation; 2) digestible true microbial protein synthesized in the rumen; and 3) a correction for endogenous protein losses in the digestive tract.
Each feed also has a rumen Degraded Protein Balance $^{\mathrm{OEB}}$ value, called OEB in Dutch, which shows the (im)balance between microbial protein synthesis potentially possible from available rumen degradable protein and that potentially possible from the energy extracted during anaerobic fermentation in the rumen. When OEB is positive, it indicates the potential loss of $\mathrm{N}$ from the rumen. When negative, microbial protein synthesis may be impaired because of a shortage of $\mathrm{N}$ in the rumen. The optimum OEB value in a ration is, therefore, zero or slightly above (Tamminga et al., 1994).

The NRC dairy model (2001) introduced the concepts of metabolizable protein (MP), defined as true protein that is digested and absorbed by the intestine, and contributed by 1) ruminally undegraded feed CP, 2) ruminally synthesized microbial CP $\left(\mathbf{M C P}^{\mathbf{N R C}}\right)$, and 3) endogenous CP from rumen (ECP). Based on the data from NRC dairy model (NRC, 2001), the rumen Degraded Protein Balance ${ }^{\mathrm{NRC}}$ can be calculated, and it reflects the difference between the potential microbial protein synthesis based on ruminally degraded feed $\mathrm{CP}$ and that based on TDN as energy available for microbial fermentation in the rumen.

Although the principles of these two models are similar, some of the factors used in quantifying calculations and some concepts differ. The objective of this study was to compare the DVE/OEB system and the NRC-2001 model in the prediction of potential nutrient supply to dairy cows from selected forages: alfalfa (Medicago sativa L.) and timothy (Phleum pratense L.). In addition, the effects of variety and cutting stage of the forages on potential nutrient supply to dairy cows were studied.

\section{MATERIALS AND METHODS}

\section{Forages}

Two commonly grown forages: alfalfa and timothy with two varieties at three cutting times were used to compare the two models in the prediction of nutrient supply to dairy cows. Alfalfa (Pioneer and Beaver) and timothy (Climax and Joliette) cut at three stages $(1=$ $1 \mathrm{wk}$ before the commercial cut; which was early bud for alfalfa varieties and joint for timothy varieties; 2 = at the commercial cutting stage; which was late bud stage for alfalfa varieties and prebloom head stage for timothy varieties; $3=1$ wk after the commercial cut; which was early bloom for alfalfa varieties and full head for timothy varieties), were grown at different locations $(n=3)$ in Saskatchewan in 2001. These forage samples were supplied by Elcan Forage, Inc. (Saskatchewan, Canada). The detailed growth and climate conditions, estimated maturity stages and sampling 
procedure were previously described by Markert and Christensen (2002) and $\mathrm{Yu}$ et al. (2002a). The freshcut samples were dried at $55^{\circ} \mathrm{C}$ in a forced-air oven to a constant weight, then allowed to cool to ambient temperature and ground through a 2-mm screen (Laboratory Hammer Mill, Christry \& Norris, Ltd., England) for determining rumen degradation characteristics. The subsamples of the 2-mm ground materials were further ground through a 1-mm screen (Retsch ZM-1, Brinkmann Instruments (Canada) Ltd., Ontario) for chemical analysis.

\section{Rumen In Vitro Assay}

Rumen in vitro digestibility of neutral detergent fiber (IVNDFD) of timothy and alfalfa $(2 \mathrm{~mm})$ after a 48-h incubation was determined using the Tilley and Terry procedure (Marten and Barnes, 1980).

\section{Estimation of Total Digestible Nutrients}

A summative approach was used to derive the total digestible nutrient $\left(\mathrm{TDN}_{1 \mathrm{x}}\right.$; NRC, 2001). In this approach, the concentrations (\% DM) of truly digestible nonfiber carbohydrate, crude protein (CP), and ether extract (EE) for each feed were estimated (Weiss et al., 1992) according to the equations in the NRC dairy model (2001). Truly digestible NDF (tdNDF) was obtained using a 48-h rumen in vitro assay (NRC, 2001), calculated as: $\operatorname{tdNDF}(\% \mathrm{DM})=\operatorname{IVNDFD}(\%) \times \mathrm{NDF}$ (\% DM).

\section{In Situ Rumen Incubation Assay}

Animal and diet. Two dry Holstein-Friesian cows fitted with large rumen cannulas with an internal diameter of $10 \mathrm{~cm}$ were housed in tie stalls and bedded with straw at the dairy experimental station of the University of Saskatchewan. Each cow received daily 15 -kg TMR, consisting of $27.5 \%$ pelleted concentrate [containing $55.8 \%$ barley, $11.7 \%$ soybean meal, $10.3 \%$ canola meal, $5 \%$ oats, $4.1 \%$ wheat, $3.3 \%$ wheat distillers dried grains, $3 \%$ mineral-vitamin mix, $2.2 \%$ corn gluten meal, $2.1 \%$ molasses, $0.7 \%$ canola oil, $0.6 \%$ cobalt-iodized salt, $0.6 \%$ sodium bicarbonate, $0.3 \%$ dynamate (International Minerals and Chemicals Corp., Mundelein, IL, USA), $0.05 \%$ niacin-magnesium mix, and $0.05 \%$ ground limestone], $55 \%$ barley silage, $12.5 \%$ alfalfa hay, and $5 \%$ dehydrated alfalfa. Both cows were individually fed twice daily at 0800 and $1600 \mathrm{~h}$. Water was always available. Cows had free access to exercise grounds. The animals used in the experiment were cared for in accordance with the guidelines of the Canadian Council on Animal Care (1993).
In situ rumen degradation procedure. Rumen degradation characteristics of the forage samples were determined using the in situ method as modified by McKinnon et al. (1995). All treatments were incubated in number-coded, commercially-made polyester bags $(10 \times 20 \mathrm{~cm}$; ANKOM Company, Fairport, NY $)$ with pore size of $53 \pm 10 \mu \mathrm{m}$. These bags were tied $2 \mathrm{~cm}$ below the top with a ratio of sample size-to-bag-surface-area of $27.8 \mathrm{mg} / \mathrm{cm}^{2}$. Incubations were carried out for 72 , $48,24,12,8,4$, and $2 \mathrm{~h}$, bags were inserted at 2100 (d 1), 2100 (d 2), 2100 (d 3), 0900 (d 4), 1300 (d 4), 1700 (d 4), 1900 (d 4), and all were removed at 2100 h (d 4). All treatments were randomly allocated over cows. This is because an initial experiment (Markert and Christensen, 2002) showed no significant animal effect on rumen degradation characteristics of the alfalfa and timothy forages. After incubation, the bags were removed from rumen and rinsed under a cold stream of tap water to remove excess ruminal contents and to stop microbial activity. Then the bags were washed without detergent by hand and subsequently dried at $55^{\circ} \mathrm{C}$ for $24 \mathrm{~h}$. The 0 -h incubation samples were washed under the same conditions. The residues were pooled according to forage species, variety, stage, and incubation time and then ground through a 1-mm screen (Retsch ZM-1, Brinkmann Instruments, Ltd., Ontario, Canada) for chemical analysis.

Rumen degradation model. The rumen degradation characteristics described by the first order kinetics degradation model (Ørskov and McDonald, 1979), modified by Robinson et al. (1986), Tamminga et al. (1990), and Tamminga et al. (1994) were soluble fraction (A, \%) which was determined from the 0 -h incubations, undegradable fraction $(\mathrm{C}, \%)$, insoluble fraction (B, \%), which was degraded exponentially, the degradation rate $(\mathrm{Kd}, \% / \mathrm{h})$, and lag time $(\mathrm{T} 0, \mathrm{~h})$. As each component has its own pattern of rumen degradation, to describe its degradation accurately, the models used for each component were different. The results were calculated using the NLIN (nonlinear) procedure of the statistical package of SAS (1991) using iterative least-squares regression (Gauess-Newton method) by the following first order kinetics equations:

$$
\begin{aligned}
\mathrm{OM}: R(\mathrm{t}) & =\mathrm{C}+(100-\mathrm{A}-\mathrm{C}) \times \mathrm{e}^{-\mathrm{Kd} \times(\mathrm{t}-\mathrm{T} 0)}, \\
\mathrm{CP}: R(\mathrm{t}) & =\mathrm{C}+(100-\mathrm{A}-\mathrm{C}) \times \mathrm{e}^{-\mathrm{Kd} \times \mathrm{t}},
\end{aligned}
$$

where, $\mathrm{R}(\mathrm{t})=$ residue $(\%)$ of the amount of incubated material after $\mathrm{t} h$ of rumen incubation.

For OM, rumen degradation was described by assuming three fractions (A, B, and C) with lag time T0. For $\mathrm{CP}$, rumen degradation was described by assuming three fractions (A, B, and C) without lag time (T0 =0) (Ørskov and McDonald, 1979). 
Further calculations were:

For CP: Fraction of ruminally degraded feed CP was calculated as: \% RDP $=\mathrm{A}+(\mathrm{B} \times \mathrm{Kd}) /(\mathrm{Kd}+\mathrm{Kp})$; fraction of rumen undegraded feed $\mathrm{CP}$ was calculated as: $\% \mathrm{RUP}=\mathrm{C}+(\mathrm{B} \times \mathrm{Kp}) /(\mathrm{Kd}+\mathrm{Kp})$, where, $\mathrm{Kp}$ of $4 \% / \mathrm{h}$ was adopted for a forage (Tamminga et al., 1994).

For OM: fraction of ruminally degraded feed OM was calculated as: \% RDOM $=\mathrm{A}+(\mathrm{B} \times \mathrm{Kd}) /(\mathrm{Kd}+\mathrm{Kp})$; fraction of rumen undegraded feed $\mathrm{OM}$ was calculated as: $\% \mathrm{RUOM}=\mathrm{C}+(\mathrm{B} \times \mathrm{Kp}) /(\mathrm{Kd}+\mathrm{Kp})$, where, $\mathrm{Kp}$ of $4 \% / \mathrm{h}$ was adopted for a forage.

\section{Chemical Analysis}

The DM, ash, EE, and N contents were analyzed according to the procedure of AOAC (1990). The acid detergent fiber (ADF), NDF, and acid detergent lignin (ADL) values were analyzed according to the procedures of Van Soest et al. (1991).

\section{The DVE/OEB System}

The detailed concepts and formulas of the DVE/OEB system are provided by Tamminga et al. (1994). The following is a brief explanation to show how to calculate and predict protein supply to the small intestine of dairy cows as a result of feeding the two forage types as affected by variety and cutting stage.

Calculation of FOM and RUP ${ }^{D E V}$. In the DVE/ OEB system, bypassing rumen microbial degradation of feed protein $\left(\mathrm{RUP}^{\mathrm{DEV}}\right)$ was calculated as: $\mathrm{RUP}^{\mathrm{DEV}}=$ $1.11 \times \mathrm{CP} \times \% \mathrm{RUP}$, where, $\mathrm{RUP}^{\mathrm{DEV}}$ and $\mathrm{CP}$ in $\mathrm{g} / \mathrm{kg}$ DM. The factor 1.11 is taken from the French PDIsystem (Verite et al., 1987). This represents the regression coefficient of in vivo on in situ degradation data. The content of OM fermented in the rumen (FOM) is calculated as: $\mathrm{FOM}=\mathrm{OM} \times \% \mathrm{RUOM}$, where, $\mathrm{FOM}$ and $\mathrm{OM}$ are in $\mathrm{g} / \mathrm{kg}$ DM (Muia et al., 2001).

Microbial protein synthesis in the rumen. Microbial protein synthesized in the rumen based on rumen fermented organic matter $\left(\mathbf{M C P}_{\mathbf{F O M}}\right)$ was estimated as: $\mathrm{MCP}_{\mathrm{FOM}}=0.15 \times \mathrm{FOM}$, where, $\mathrm{MCP}_{\mathrm{FOM}}$ in $\mathrm{g} / \mathrm{kg}$ DM. The factor 0.15 means that per kg FOM, $150 \mathrm{~g}$ of microbial protein is assumed to be synthesized (Tamminga et al., 1994).

The content of true protein supplied to the small intestine (TPSI) was calculated as: TPSI $=\mathrm{RUP}^{\mathrm{DEV}}+$ $0.75 \times \mathrm{MCP}_{\mathrm{FOM}}$, where, TPSI is in $\mathrm{g} / \mathrm{kg} \mathrm{DM}$. The factor 0.75 means that $75 \%$ of microbial $\mathrm{N}$ is present in amino acids; the remaining is $\mathrm{N}$ in nucleic acids.

Intestinal digestion of feed and microbial protein. The previously discussed RUP ${ }^{\mathrm{DEV}}$ and TPSI must be corrected for incomplete digestion and endogenous secretions (Tamminga et al., 1994). A correction is needed for protein losses due to incomplete digestion and from endogenous secretions. True digestibility of microbial protein is assumed to be $85 \%$ (Egan et al., 1985) and, therefore, the amount of truly absorbed rumen synthesized microbial protein in the small intestine $\left(\mathbf{A M C P}^{\mathbf{D V E}}\right)$ was estimated as: $\mathrm{AMCP}^{\mathrm{DVE}}=0.85$ $\times 0.75 \times \mathrm{MCP}_{\mathrm{FOM}}$, where, $\mathrm{AMCP}^{\mathrm{DVE}}$ is in $\mathrm{g} / \mathrm{kg} \mathrm{DM}$.

For feed ingredients, the content of truly absorbed bypass feed protein in the small intestine (ARUP ${ }^{\mathrm{DVE}}$ ) was calculated as: $A R U P^{D V E}=R P^{D V E}-U C P$, where, the amount of potential undigested $\mathrm{CP}(\mathrm{UCP})$ is calculated as: $\mathrm{UCP}=\mathrm{CP} \times \% \mathrm{U}_{\mathrm{CP}}$, where, $\% \mathrm{U}_{\mathrm{CP}}$ was protein residue remaining after an in situ incubation of 336 h. It was assumed that undegradable CP after a 336$\mathrm{h}$ incubation is indigestible in the small intestine (Tamminga et al., 1994; Muia et al., 2001). In this experiment, $\% \mathrm{U}_{\mathrm{CP}}$ was determined following a $72-\mathrm{h}$ in situ incubation. This is because a previous study showed that further incubation from 72 to $336 \mathrm{~h}$ resulted in no further digestion in alfalfa (data not shown).

Endogenous protein losses in the small intestine. In the DVE/OEB system, the endogenous protein losses in the digestive tract (ENDP) is related to the amount of undigested DM (UDM) excreted in the feaces. According to the DVE/OEB system, $75 \mathrm{~g}$ of absorbed protein per kg undigested DM in fecal excretion is required to compensate for the endogenous losses. Therefore, endogenous protein losses in the digestive tract are estimated as: $\mathrm{ENDP}=75 \times$ undigested DM, where, undigested DM and ENDP are in $\mathrm{g} / \mathrm{kg} \mathrm{DM}$; $\mathrm{UDM}=$ undigested $\mathrm{OM}+$ undigested inorganic matter, where, undigested $\mathrm{OM}=\mathrm{OM} \times \% \mathrm{U}_{\mathrm{om}}, \% \mathrm{U}_{\mathrm{om}}$ was residue of forage $\mathrm{OM}$ following an incubation of $72 \mathrm{~h}$, and undigested inorganic matter $=\mathrm{ASH} \times 35 \%(\mathrm{CVB}$, 1996).

Truly digested and absorbed protein in the small intestine. Truly digested and absorbed protein in the small intestine (DVE) are contributed by 1) feed protein escaping rumen degradation $\left(\mathrm{RUP}^{\mathrm{DVE}}\right), 2$ ) microbial protein synthesized in the rumen $\left(\mathrm{MCP}_{\mathrm{FOM}}\right)$, and 3) a correction for endogenous protein losses in the digestive tract (ENDP). Therefore, the DVE value was estimated as: DVE $=\mathrm{ARUP}^{\mathrm{DVE}}+\mathrm{AMCP}_{\mathrm{FOM}}-$ ENDP, where, DVE is in $\mathrm{g} / \mathrm{kg}$ DM.

Degraded protein balance. The Degraded Protein Balance $^{\text {OEB }}$ is a balance between microbial protein synthesis from rumen degradable $\mathrm{CP}$ and that from the energy extracted during anaerobic fermentation in the rumen. Therefore, the Degraded Protein Balance ${ }^{\mathrm{OEB}}$ value was estimated as: microbial protein synthesized in the rumen based on rumen degraded feed crude protein $\left(\mathbf{M C P}_{\mathbf{R D P}}{ }^{\mathbf{D V E}}\right)-\mathbf{M C P}_{\mathrm{FOM}}$, where, all parameters are in $\mathrm{g} / \mathrm{kg} \mathrm{DM}, \mathrm{MCP}_{\mathrm{RDP}}{ }^{\mathrm{DVE}}=\mathrm{CP}-$ 
$1.11 \times \%$ RUP. When the Degraded Protein Balance is positive, it indicates the potential loss of $\mathrm{N}$ from the rumen. When it is negative, microbial protein synthesis may be impaired, because of a shortage of $\mathrm{N}$ in the rumen. The optimum value of the Degraded Protein Balance $^{\mathrm{OEB}}$ in a ration is, therefore, zero or slightly above zero (Tamminga et al., 1994).

\section{The NRC-2001 Model}

The detailed concepts and formulas are provided by NRC (2001). A brief explanation is as follows:

Calculation of $\boldsymbol{R D P} P^{N R C}$ and $R U P^{N R C}$. Using the NRC-2001 model, the ruminally undegraded feed CP was calculated as: $\mathrm{RUP}^{\mathrm{NRC}}=\mathrm{CP} \times \% \mathrm{RUP}$; the rumen degraded feed protein was calculated as: $\mathrm{RDP}^{\mathrm{NRC}}=\mathrm{CP}$ $\times \%$ RDP, where, a Kp was $4 \% / h$; RDP ${ }^{\mathrm{NRC}}$, $\mathrm{RUP}^{\mathrm{NRC}}$ and $\mathrm{CP}$ in $\mathrm{g} / \mathrm{kg} \mathrm{DM}$.

Rumen microbial protein synthesis. Ruminally synthesized microbial CP was calculated as: $\mathrm{MCP}^{\mathrm{NRC}}$ $(\mathrm{g} / \mathrm{kg} \mathrm{DM})=0.13 \times \mathrm{TDN}$, when $\mathrm{RDP}^{\mathrm{NRC}}$ exceeded 1.18 $\times$ TDN-predicted MCP $\left(\mathrm{MCP}_{\mathrm{TDN}}\right)$. When $\mathrm{RDP}^{\mathrm{NRC}}$ was less than $1.18 \times$ TDN-predicted $\mathrm{MCP}\left(\mathrm{MCP}_{\mathrm{TDN}}\right)$, $\mathrm{MCP}^{\mathrm{NRC}}$ was calculated as 0.85 of $\mathrm{RDP}^{\mathrm{NRC}}\left(\mathrm{MCP}_{\mathrm{RDP}}\right)$. The factor 0.13 means that per $\mathrm{kg}$ TDN, $130 \mathrm{~g}$ of microbial protein CP is assumed to be synthesized.

Intestinal digestion of feed and microbial protein. In the NRC model (2001), digestibility and true protein of ruminally synthesized microbial $\mathrm{CP}$ are assumed to be $80 \%$; therefore, the amount of truly absorbed $\mathbf{M C P}^{\mathrm{NRC}}\left(\mathbf{A M C P}^{\mathbf{N R C}}\right)$ was estimated as: $\mathrm{AMCP}^{\mathrm{NRC}}=0.80 \times 0.80 \times \mathrm{MCP}^{\mathrm{NRC}}$, where, $\mathrm{AMCP}^{\mathrm{NRC}}$ is in $\mathrm{g} / \mathrm{kg} \mathrm{DM}$.

For feed ingredients, truly absorbed rumen undegraded feed protein in the small intestine (ARUP ${ }^{\mathrm{NRC}}$ ) was calculated as: $\mathrm{ARUP}^{\mathrm{NRC}}=\mathrm{RUP}^{\mathrm{NRC}}-\mathrm{UCP}$, where, $\mathrm{UCP}=$ the amount of potential undigested $\mathrm{CP}$, calculated as: $\mathrm{CP} \times \% \mathrm{U}_{\mathrm{CP}}$.

Rumen endogenous protein in the small intestine. Rumen endogenous $\mathrm{CP}(\mathrm{g} / \mathrm{kg} \mathrm{DM})$ according to the NRC model (2001) can be calculated as: ECP = $6.25 \times 1.9 \times \mathrm{DM}(\mathrm{g} / \mathrm{kg})$. Assuming that $50 \%$ of rumen endogenous CP passes to the duodenum and $80 \%$ of rumen endogenous CP is true protein (NRC, 2001), the truly absorbed endogenous protein in the small intestine $(\mathbf{A E C P})$ was estimated as: $\mathrm{AECP}=0.50 \times$ $0.80 \times \mathrm{ECP}$, where, AECP and ECP are in $\mathrm{g} / \mathrm{kg} \mathrm{DM}$.

Total metabolizable protein. Metabolizable protein in the NRC dairy model (NRC, 2001) is contributed by 1) digestible $\mathrm{RUP}^{\mathrm{NRC}}$, 2) digestible $\mathrm{MCP}^{\mathrm{NRC}}$, and 3) $\mathrm{ECP}$, calculated as: $\mathrm{MP}=\mathrm{ARUP}^{\mathrm{NRC}}+\mathrm{AMCP}^{\mathrm{NRC}}$ + AECP, where, MP is in $\mathrm{g} / \mathrm{kg}$ DM.

Degraded protein balance. Based on the data from the NRC dairy model (2001), the Degraded Pro- tein Balance ${ }^{\mathrm{NRC}}(\mathrm{g} / \mathrm{kg} \mathrm{DM})$ can be calculated. It reflects the difference between the potential microbial protein synthesis based on ruminally degraded feed crude protein $\left(\mathrm{RDP}^{\mathrm{NRC}}\right)$ and that based on energy (TDN) available for microbial fermentation in the rumen, calculated as: $\mathrm{RDP}-1.18 \mathrm{MCP}_{\mathrm{TDN}}$, where, the Degraded Protein Balance $^{\mathrm{NRC}}$ value is in $\mathrm{g} / \mathrm{kg} \mathrm{DM}$.

\section{Statistical Analysis}

Statistical analyses were performed using the GLM procedure of SAS (1991). The model used for the analysis was:

$$
Y_{\mathrm{jk}(\mathrm{i})}=\mu+F_{\mathrm{i}}+V_{\mathrm{j}(\mathrm{a})}+V_{\mathrm{j}(\mathrm{t})}+M_{\mathrm{k}(\mathrm{a})}+M_{\mathrm{k}(\mathrm{t})}+e_{\mathrm{ijk}},
$$

where, $Y_{k l(i)}$ is an observation of the dependent variable for the variety $j$ at maturity $k$ in the forage $i$; $\mu$ is the population mean for the variable; $F_{i}$ is the forage type $i, i=\mathrm{a}, \mathrm{t}$; $\mathrm{a}$ is for alfalfa, and $\mathrm{t}$ is for timothy; $V_{j \text { (a) }}$ is the effect of forage variety nested within alfalfa; $V_{j}$ (t) is the effect of forage variety nested within timothy; $M_{k(a)}$ is the effect of forage maturity nested within alfalfa; $M_{k(t)}$ is the effect of forage variety nested within timothy; and $e_{i j k}$ is the random error associated with the observation $j k(i)$.

Treatments contrasts (SAS, 1991; alfalfa vs. timothy; Pioneer alfalfa vs. Beaver alfalfa; Climax timothy vs. Joliette timothy, etc.) were used to determine treatment differences. Significance was declared at $P<0.05$.

The PROC CORR and PROC REG (SAS, 1991) was used for linear correlation and regression analysis between predicted values from the DVE/OEB system and the NRC-2001 model ( $\mathrm{MCP}_{\mathrm{FOM}}$ vs. $\mathrm{MCP}_{\mathrm{TDN}}$; $\mathrm{MCP}_{\mathrm{RDP}}{ }^{\mathrm{DVE}}$ vs. $\mathrm{MCP}_{\mathrm{RDP}}{ }^{\mathrm{NRC}}$; DVE vs. MP; and Degraded Protein Balance ${ }^{\mathrm{OEB}}$ vs. Degraded Protein Balance $\left.^{\mathrm{NRC}}\right)$. Pearson correlation coefficients $(\mathrm{R})$ and regression equation are presented.

\section{RESULTS}

\section{Chemical Composition and Rumen Degradation Characteristics of Alfalfa and Timothy}

The effects of variety and cutting stage of alfalfa and timothy on chemical composition, in vitro rumen digestibility of $\mathrm{NDF}$, and in situ rumen degradation characteristics of $\mathrm{OM}$ and $\mathrm{CP}$ are presented in Tables 1 and 2. The detailed results and discussion on the effects of forage type, variety, and stage of cutting on chemical composition, and rumen degradation characteristics have been previously discussed (Yu et al., 2002a). 
Table 1. Effect of variety and cutting stage on chemical composition and in vitro digestibility ( $48 \mathrm{~h}$ ) of alfalfa and timothy. ${ }^{1}$

\begin{tabular}{|c|c|c|c|c|c|c|c|}
\hline \multirow[b]{2}{*}{ Item } & \multicolumn{6}{|c|}{ Chemical composition (\% DM) } & \multirow[b]{2}{*}{ IVNDFD } \\
\hline & DM & Ash & $\mathrm{CP}$ & $\mathrm{NDF}$ & $\mathrm{ADF}$ & $\mathrm{ADL}$ & \\
\hline \multicolumn{8}{|l|}{ Alfalfa } \\
\hline \multicolumn{8}{|l|}{ Pioneer } \\
\hline S1 & 92.9 & 9.9 & 20.4 & 49.8 & 32.0 & 11.4 & 41.5 \\
\hline $\mathrm{S} 2$ & 93.5 & 9.6 & 18.7 & 47.1 & 29.4 & 9.3 & 43.3 \\
\hline S3 & 92.6 & 9.4 & 17.7 & 54.3 & 32.0 & 9.3 & 41.9 \\
\hline \multicolumn{8}{|l|}{ Beaver } \\
\hline S1 & 93.5 & 10.5 & 19.9 & 48.8 & 32.1 & 9.9 & 41.1 \\
\hline $\mathrm{S} 2$ & 93.4 & 10.0 & 19.4 & 46.9 & 29.4 & 9.3 & 42.3 \\
\hline S3 & 93.2 & 9.2 & 17.4 & 49.6 & 31.0 & 10.6 & 35.0 \\
\hline \multicolumn{8}{|l|}{ Timothy } \\
\hline \multicolumn{8}{|l|}{ Climax } \\
\hline S1 & 93.7 & 7.1 & 12.8 & 67.3 & 36.6 & 6.0 & 36.2 \\
\hline $\mathrm{S} 2$ & 92.3 & 6.9 & 12.5 & 68.6 & 39.3 & 5.7 & 36.6 \\
\hline S3 & 93.0 & 6.6 & 9.7 & 70.5 & 38.8 & 5.4 & 35.4 \\
\hline \multicolumn{8}{|l|}{ Joliette } \\
\hline S1 & 93.9 & 6.9 & 9.4 & 70.1 & 39.4 & 4.7 & 29.2 \\
\hline $\mathrm{S} 2$ & 992.6 & 6.5 & 7.9 & 72.5 & 41.4 & 4.8 & 38.8 \\
\hline S3 & 93.3 & 6.3 & 6.2 & 75.0 & 42.7 & 6.4 & 32.6 \\
\hline SEM & 0.12 & 0.23 & 0.46 & 1.53 & 0.68 & 0.45 & 2.36 \\
\hline \multicolumn{8}{|l|}{ Treatment contrasts $^{2}$} \\
\hline Alfalfa vs. timothy & NS & $* * *$ & $* * *$ & $* * *$ & $* * *$ & $* * *$ & $* * *$ \\
\hline Pioneer vs. Beaver & NS & NS & NS & NS & NS & NS & NS \\
\hline Climax vs. Joliette & NS & NS & $* * *$ & $*$ & $* *$ & NS & NS \\
\hline \multicolumn{8}{|l|}{ In alfalfa } \\
\hline S1 vs. S2 & NS & NS & NS & NS & * & * & NS \\
\hline S1 vs. S3 & NS & $* *$ & $*$ & NS & NS & NS & NS \\
\hline S2 vs. S3 & $* *$ & $\dagger$ & NS & $*$ & $\dagger$ & NS & $\dagger$ \\
\hline \multicolumn{8}{|l|}{ In timothy } \\
\hline $\mathrm{S} 1$ vs. $\mathrm{S} 2$ & $* * *$ & NS & NS & NS & $*$ & NS & $\dagger$ \\
\hline S1 vs. S3 & $* *$ & * & $*$ & $*$ & $*$ & NS & NS \\
\hline S2 vs. S3 & $* *$ & NS & $\dagger$ & NS & NS & NS & NS \\
\hline
\end{tabular}

${ }^{1}$ Stage: $\mathrm{S} 1$ = $1 \mathrm{wk}$ before commercial cut (early bud for alfalfa varieties and joint for timothy varieties); $\mathrm{S} 2$ = at commercially cutting stage (late bud for alfalfa varieties and prebloom head for timothy varieties); $\mathrm{S} 3$ = 1 wk after commercial cut (early bloom for alfalfa varieties and full head for timothy varieties); ADL $=$ acid detergent lignin; IVNDFD $=$ In vitro digestibility of NDF after a 48-h incubation.

${ }^{2} \mathrm{NS}=P>0.1 ; \dagger=P<0.10 ; *=P<0.05 ; * *=P<0.01, * * *=P<0.001$.

\section{Using the DVE/OEB System to Predict Nutrient Supply to Dairy Cows}

Using the DVE/OEB system (Tamminga et al., 1994), the effects of variety and cutting stage on prediction of the nutrient supply to dairy cows from alfalfa and timothy, are presented in Tables 3 and 4 . The results showed that forage species (alfalfa vs. timothy) had a significant impact on the potential nutrient supply to dairy cows. Comparing alfalfa and timothy means, alfalfa species contained higher $(P<0.001)$ FOM, $\mathrm{MCP}_{\mathrm{RDP}}{ }^{\mathrm{DVE}}$ and $\mathrm{MCP}_{\mathrm{FOM}}$. As a result, potentially absorbed microbial protein in the small intestine $\left(\mathrm{AMCP}^{\mathrm{DEV}}\right)$ was also higher for alfalfa.

Alfalfa also contained higher $(P<0.001)$ TPSI and lower $(P<0.001)$ undigested $\mathrm{CP}$, but no difference $(P$ $>0.05$ ) was found in $\mathrm{RUP}^{\mathrm{DVE}}$. This resulted in a higher $(P<0.001)$ truly absorbed rumen undegraded protein in the small intestine for alfalfa (ARUP $\left.{ }^{\mathrm{DVE}}\right)$.
For endogenous protein losses in the small intestine, alfalfa contained lower $(P<0.001)$ undigested DM; therefore, the ENDP value for alfalfa was lower.

The most important values are DVE and the Degraded Protein Balance ${ }^{\mathrm{OEB}}$ values. The DVE value for alfalfa was nearly two times higher $(P<0.001)$ than that for timothy.

For the Degraded Protein Balance ${ }^{\mathrm{OEB}}$ value, alfalfa had a positive value, but timothy had a negative value of Degraded Protein Balance ${ }^{\mathrm{OEB}}$, indicating potential rumen $\mathrm{N}$ loss in alfalfa and a shortage with timothy.

Comparing the two varieties of alfalfa (Pioneer vs. Beaver), there were no differences $(P>0.05)$ in predicted nutrient supply to dairy cows. However, comparing the two varieties of timothy (Climax vs. Joliette), Climax was better $(P<0.05)$ than Joliette in terms of $\mathrm{MCP}_{\mathrm{RDP}}{ }^{\mathrm{DVE}}$, ARUP ${ }^{\mathrm{DVE}}, \mathrm{DVE}$, and the Degraded Protein Balance ${ }^{\mathrm{OEB}}$ values. 
Table 2. Effect of variety and cutting stage on rumen degradation characteristics of OM and CP of alfalfa and timothy. ${ }^{1}$

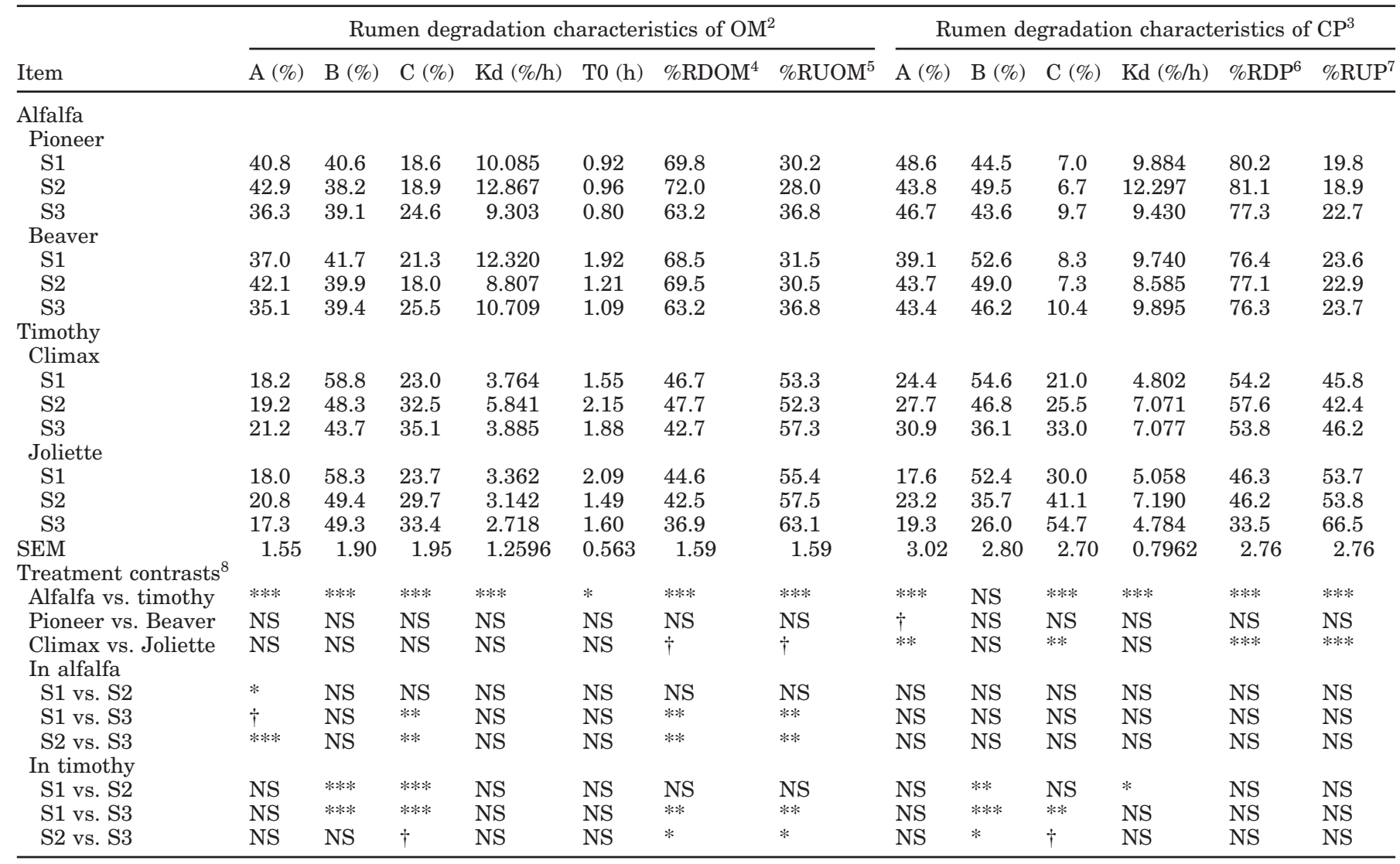

${ }^{1}$ Stage: $\mathrm{S} 1=1 \mathrm{wk}$ before commercial cut (early bud for alfalfa varieties and joint for timothy varieties); $\mathrm{S} 2=$ at commercially cutting stage (late bud for alfalfa varieties and prebloom head for timothy varieties); S3 = 1 wk after commercial cut (early bloom for alfalfa varieties and full head for timothy varieties).

${ }^{2}$ Rumen degradation model of OM: $\mathrm{R}(\mathrm{t})=\mathrm{C}+\mathrm{B} \times \mathrm{e}^{-\mathrm{Kd} \times(\mathrm{t}-\mathrm{T} 0)}$, where, $\mathrm{R}(\mathrm{t})=$ residue (in \%) of the amount of incubated material after $\mathrm{t} \mathrm{h}$ of rumen incubation.

${ }^{3}$ Rumen degradation model of $\mathrm{CP}: \mathrm{R}(\mathrm{t})=\mathrm{C}+\mathrm{B} \times \mathrm{e}^{-\mathrm{Kd} \times \mathrm{t}}$, where, $\mathrm{R}(\mathrm{t})=$ residue (in \%) of the amount of incubated material after $\mathrm{t} \mathrm{h}$ of rumen incubation and no lag time.

${ }^{4} \% \mathrm{RDOM}=\mathrm{A}+\mathrm{B} \times \mathrm{Kd} /(\mathrm{Kd}+\mathrm{Kp})$, assuming $\mathrm{Kp}=4 \% / \mathrm{h}$.

$5 \% \mathrm{RUOM}=\mathrm{C}+\mathrm{B} \times \mathrm{Kp} /(\mathrm{Kd}+\mathrm{Kp})$, assuming $\mathrm{Kp}=4 \% / \mathrm{h}$.

${ }^{6} \% \mathrm{RDP}=\mathrm{A}+\mathrm{B} \times \mathrm{Kd} /(\mathrm{Kd}+\mathrm{Kp})$, assuming $\mathrm{Kp}=4 \% / \mathrm{h}$.

${ }^{7} \% \mathrm{RUP}=\mathrm{C}+\mathrm{B} \times \mathrm{Kp} /(\mathrm{Kd}+\mathrm{Kp})$, assuming $\mathrm{Kp}=4 \% / \mathrm{h}$.

${ }^{8} \mathrm{NS}=P>0.1 ; \dagger=P<0.10 ; *=P<0.05 ; * *=P<0.01$, *** $=P<0.001$.

As alfalfa maturity advanced (stages 1 to 3 ), rumen fermented OM (FOM) was decreased $(P<0.05)$; therefore, $\mathrm{AMCP}^{\mathrm{DEV}}$ was decreased $(P<0.05)$; therefore, $\mathrm{AMCP}^{\mathrm{DEV}}$ was decreased $(P<0.05) . \mathrm{RUP}^{\mathrm{DEV}}$ was not affected $(P>0.05)$, undigested $C P$ was increased $(P<$ $0.05)$, and ARUP ${ }^{\mathrm{DEV}}$ tended to be affected $(P<0.10)$. Due to increasing undigested DM, ENDP $(P<0.05)$ was also increased. In general, the DVE value was decreased $(P<0.05)$ without affecting the Degraded Protein Balance ${ }^{\mathrm{OEB}}$ value $(P>0.05)$. Similar trends were found for timothy. With increasing stage of cutting, FOM was decreased $(P<0.05)$, $\mathrm{AMCP}^{\mathrm{DEV}}$ decreased $(P<0.05)$, ARUP ${ }^{\mathrm{DEV}}$ decreased $(P<0.05)$, and ENDP $(P<0.05)$ increased. The total DVE value in timothy was decreased $(P<0.05)$ without affecting the Degraded Protein Balance ${ }^{\mathrm{OEB}}$ value $(P>0.05)$ as maturity increased.

\section{Using the NRC-2001 Model to Predict Nutrient Supply to Dairy Cows}

Using the NRC-2001 model, the effects of variety and cutting stage on potential nutrient supply to dairy cows from alfalfa and timothy are presented in Tables 5 and 6. Comparing alfalfa and timothy means, alfalfa contained higher $(P<0.001) \mathrm{TDN}_{1 \mathrm{x}}$, therefore, resulting in a higher $(P<0.001) \mathrm{MCP}_{\mathrm{TDN}}$. It also contained higher $\operatorname{RDP}^{\mathrm{NRC}}(P<0.001)$, therefore, resulting 
Table 3. Prediction of truly digested and absorbed rumen synthesized microbial (MCP) and undegraded feed protein (RUP) in the small intestine to dairy cows from alfalfa and timothy using the DVE/OEB system: effect of variety and cutting stage. ${ }^{1}$

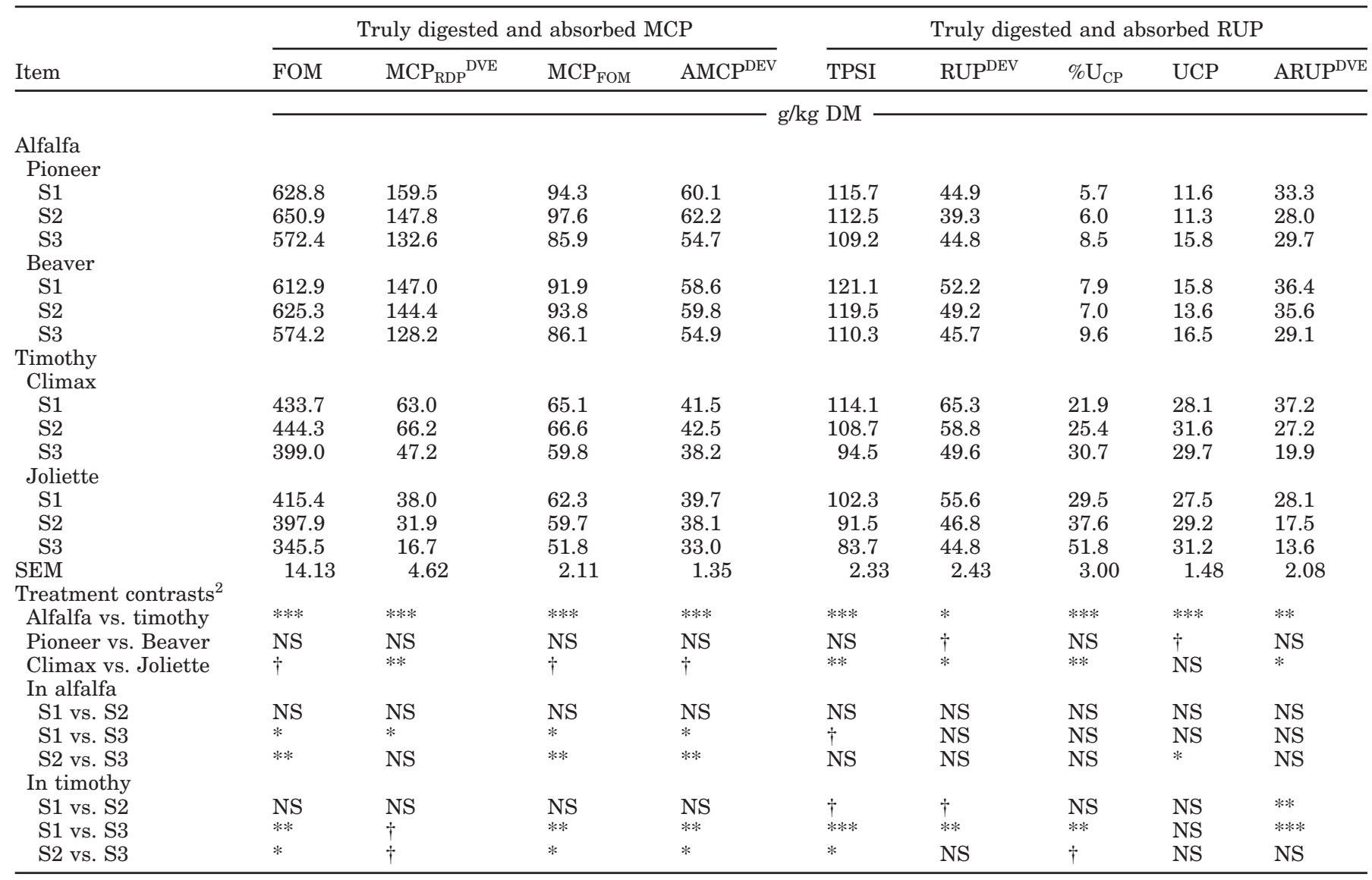

${ }^{1}$ Stage: $\mathrm{S} 1$ = $1 \mathrm{wk}$ before commercial cut (early bud for alfalfa varieties and joint for timothy varieties); S2 = at commercially cutting stage (late bud for alfalfa varieties and prebloom head for timothy varieties); S3 $=1$ wk after commercial cut (early bloom for alfalfa varieties and full head for timothy varieties). DVE = truly digested and absorbed protein in the small intestine ( $\mathrm{g} / \mathrm{kg} \mathrm{DM})$, contributed by 1$)$ feed protein escaping rumen degradation $\left(\mathrm{RUP}^{\mathrm{DVE}}\right), 2$ ) microbial protein synthesized in the rumen $\left(\mathrm{MCP}_{\mathrm{FOM}}\right)$, and 3 ) a correction for endogenous protein losses in the digestive tract (ENDP), calculated as: DVE = ARUP ${ }^{\mathrm{DVE}}+\mathrm{AMCP}^{\mathrm{DVE}}-\mathrm{ENDP}(\mathrm{DVE} / \mathrm{OEB}$ system: Tamminga et al., 1994$)$. $\mathrm{FOM}=$ fermented organic matter; AMCP $=$ truly absorbed MCP; TPSI $=$ true protein supplied to the small intestine; ARUP ${ }^{\mathrm{DVE}}=$ truly absorbed bypass feed in the small intestine.

${ }^{2} \mathrm{NS}=P>0.1 ; \dagger=P<0.10 ; *=P<0.05 ; * *=P<0.01, * * *=P<0.001$.

in higher $(P<0.001) \mathrm{MCP}_{\mathrm{RDP}}{ }^{\mathrm{NRC}}$. Alfalfa promoted increased synthesis of higher $\operatorname{MCP}^{\mathrm{NRC}}(P<0.001)$, therefore, higher $\mathrm{AMCP}^{\mathrm{NRC}}(P<0.001)$.

For the truly absorbed rumen undegraded protein in the small intestine, there was no effect of species (alfalfa vs. timothy) on RUP ${ }^{\mathrm{NRC}}(P>0.05)$, but alfalfa was lower $(P<0.001)$ in intestinal UCP, which resulted in higher $(P<0.001)$ truly absorbed rumen undegraded protein in the small intestine (ARUP $\left.{ }^{\mathrm{NRC}}\right)$.

Total MP, contributed from AMCP ${ }^{\mathrm{NRC}}$, ARUP ${ }^{\mathrm{NRC}}$, and AECP, in alfalfa was higher $(P<0.001)$ than that in timothy. Alfalfa also had a higher $(P<0.001)$ Degraded Protein Balance ${ }^{\mathrm{NRC}}$.

Comparing the two varieties of alfalfa (Pioneer vs. Beaver $)$, no differences $(P>0.05)$ in predicted nutrient supply to dairy cows were found using NRC model
(2001). However, comparing the two varieties of timothy (Climax vs. Joliette), Climax had a superior nutritive value than Joliette. It had higher AMCP ${ }^{\mathrm{NRC}}(P<$ $0.001)$ and $\operatorname{ARUP}^{\mathrm{NRC}}(P<0.001)$ but similar AECP $(P$ $>0.05)$. Therefore, Climax was higher $(P<0.001)$ in total MP and the Degraded Protein Balance ${ }^{\mathrm{NRC}}$ value.

As alfalfa maturity advanced (stages 1 to 3), only AECP decreased $(P<0.05)$. For timothy, increasing stage of cutting decreased AMCP ${ }^{\mathrm{NRC}}(P<0.10)$, AR$\mathrm{UP}^{\mathrm{NRC}}(P<0.05), \operatorname{AECP}(P<0.05), \mathrm{MP}(P<0.05)$, and Degraded Protein Balance ${ }^{\mathrm{NRC}}(P<0.10)$.

\section{Comparison of Predictions from the DVE/OEB System and the NRC-2001 Model}

The mean, standard deviation, and range of the predicted values calculated according to the DVE/OEB 
Table 4. Prediction of endogenous protein losses in the digestive tract, total truly digested and absorbed protein in the small intestine (DVE), and degraded protein balance $(\mathrm{g} / \mathrm{kg} \mathrm{DM})$ to dairy cows from alfalfa and timothy using the DVE/OEB system: effect of variety and cutting stage. ${ }^{1}$

\begin{tabular}{|c|c|c|c|c|}
\hline \multirow[b]{2}{*}{ Item } & \multicolumn{2}{|c|}{ Endogenous protein losses } & \multirow[b]{2}{*}{ DVE } & \multirow{2}{*}{$\begin{array}{l}\text { Degraded } \\
\text { protein } \\
\text { balance } \\
\text { OEB } 2\end{array}$} \\
\hline & UDM & ENDP & & \\
\hline & & , & & 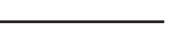 \\
\hline \multicolumn{5}{|l|}{ Alfalfa } \\
\hline \multicolumn{5}{|l|}{ Pioneer } \\
\hline $\mathrm{S} 1$ & 177.4 & 13.3 & 80.1 & 65.2 \\
\hline $\mathrm{S} 2$ & 181.5 & 13.6 & 76.7 & 50.2 \\
\hline $\mathrm{S} 3$ & 233.5 & 17.5 & 66.9 & 46.8 \\
\hline \multicolumn{5}{|l|}{ Beaver } \\
\hline $\mathrm{S} 1$ & 200.3 & 15.0 & 80.0 & 55.1 \\
\hline $\mathrm{S} 2$ & 179.5 & 13.5 & 81.9 & 50.6 \\
\hline $\mathrm{S} 3$ & 239.4 & 18.0 & 66.1 & 42.0 \\
\hline \multicolumn{5}{|l|}{ Timothy } \\
\hline \multicolumn{5}{|l|}{ Climax } \\
\hline $\mathrm{S} 1$ & 256.7 & 19.3 & 59.4 & -2.0 \\
\hline $\mathrm{S} 2$ & 303.7 & 22.8 & 46.9 & -0.4 \\
\hline S3 & 355.0 & 26.6 & 31.4 & -12.7 \\
\hline \multicolumn{5}{|l|}{ Joliette } \\
\hline $\mathrm{S} 1$ & 274.8 & 20.6 & 47.2 & -24.4 \\
\hline $\mathrm{S} 2$ & 333.1 & 25.0 & 30.6 & -27.8 \\
\hline S3 & 386.8 & 29.0 & 17.6 & -35.1 \\
\hline SEM & 11.40 & 0.85 & 3.13 & 4.29 \\
\hline \multicolumn{5}{|l|}{ Treatment contrasts ${ }^{3}$} \\
\hline Alfalfa vs. timothy & $* * *$ & $* * *$ & $* * *$ & $* * *$ \\
\hline Pioneer vs. Beaver & NS & NS & NS & NS \\
\hline Climax vs. Joliette & NS & NS & $*$ & $* * *$ \\
\hline \multicolumn{5}{|l|}{ In alfalfa } \\
\hline $\mathrm{S} 1$ vs. S2 & NS & NS & NS & NS \\
\hline $\mathrm{S} 1$ vs. $\mathrm{S} 3$ & $* *$ & $* *$ & $*$ & $\dagger$ \\
\hline S2 vs. S3 & $* * *$ & $* * *$ & $*$ & NS \\
\hline \multicolumn{5}{|l|}{ In timothy } \\
\hline S1 vs. S2 & $* * *$ & $* * *$ & $* *$ & NS \\
\hline S1 vs. S3 & $* * *$ & $* * *$ & $* * *$ & NS \\
\hline S2 vs. S3 & $* * *$ & $* * *$ & $*$ & NS \\
\hline
\end{tabular}

${ }^{1}$ Stage: $\mathrm{S} 1$ = $1 \mathrm{wk}$ before commercial cut (early bud for alfalfa varieties and joint for timothy varieties); $\mathrm{S} 2$ = at commercially cutting stage (late bud for alfalfa varieties and prebloom head for timothy varieties); $\mathrm{S} 3=1 \mathrm{wk}$ after commercial cut (early bloom for alfalfa varieties and full head for timothy varieties). DVE = truly digested and absorbed protein in the small intestine ( $/ \mathrm{kg} \mathrm{DM})$, contributed by 1 ) feed protein escaping rumen degradation (RUP $\left.{ }^{D V E}\right), 2$ ) microbial protein synthesized in the rumen $\left(\mathrm{MCP}_{\mathrm{FOM}}\right)$, and 3 ) a correction for endogenous protein losses in the digestive tract (ENDP), calculated as: DVE $=$ ARUP ${ }^{D V E}$ $+\mathrm{AMCP}^{\mathrm{DVE}}-\mathrm{ENDP}$ (DVE/OEB system: Tamminga et al., 1994). FOM = fermented OM; AMCP = truly absorbed MCP; TPSI = true protein supplied to the small intestine; ARUP ${ }^{\mathrm{DVE}}=$ truly absorbed bypass feed in the small intestine; UDM = undigested DM.

${ }^{2}$ Degraded protein balance ${ }^{\mathrm{OEB}}(\mathrm{g} / \mathrm{kg} \mathrm{DM})$, reflecting the difference between the potential microbial protein synthesis based on degraded feed CP and that based on energy available for microbial fermentation in the rumen, calculated as: $\mathrm{MCP}_{\mathrm{RDP}}{ }^{\mathrm{DVE}}-\mathrm{MCP}_{\mathrm{FOM}}(\mathrm{DVE} / \mathrm{OEB}$-system: Tamminga et al., 1994).

${ }^{3} \mathrm{NS}=P>0.1 ; \dagger=P<0.10 ; *=P<0.05 ; * *=P<0.01, * * *=P<0.001$.

system and the NRC-2001 model, and the correlations between two models are in Tables 7 and 8 . The results show that the predicted values from the DVE/OEB system and the NRC-2001 model had significant correlations $(P<0.001)$ with high $\mathrm{R}$ values ranging from 0.96 to 0.99 . The standard deviations and ranges of the predicted values for each treatment were of a similar magnitude. Using the DVE/OEB system, the overall mean for microbial protein supply based on energy, or on ruminally degraded protein were higher $(+9.4$ and $+9.8 \mathrm{~g} / \mathrm{kg} \mathrm{DM}$, respectively), but the total absorbed protein in the small intestine and the Degraded Protein Balance values were lower $(-8.6$ and $-2.2 \mathrm{~g} / \mathrm{kg}$ $\mathrm{DM}$, respectively) in comparison to that predicted by the NRC-2001 dairy model.

Linear regression of the predicted nutritional values between the DVE/OEB system and the NRC-2001 model are as follows:

1. $\mathrm{MCP}_{\mathrm{FOM}}=1.25( \pm 0.08) \times \mathrm{MCP}_{\mathrm{TDN}}$, where, $\mathrm{R}^{2}=0.93, P<0.0001, \mathrm{RSD}=4.59$.

2. $\mathrm{MCP}_{\mathrm{RDP}}{ }^{\mathrm{DVE}}=1.18( \pm 0.003) \times \mathrm{MCP}_{\mathrm{RDP}}{ }^{\mathrm{NRC}}-5.40$ $( \pm 0.31)$ 
Table 5. Prediction of truly digested and absorbed rumen synthesized microbial (MCP) and undegraded feed protein (RUP) in the small intestine $(\mathrm{g} / \mathrm{kg} \mathrm{DM})$ to dairy cows from alfalfa and timothy using the NRC-2001 Dairy model: effect of variety and cutting stage. ${ }^{1}$

\begin{tabular}{|c|c|c|c|c|c|c|c|c|c|c|}
\hline Item & \multicolumn{6}{|c|}{ Truly digested and absorbed rumen synthesized MCP } & \multicolumn{4}{|c|}{ Truly digested and absorbed RUP } \\
\hline & $(\% \mathrm{DM})$ & & & & 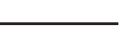 & kg DM & & 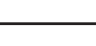 & & \\
\hline \multicolumn{11}{|l|}{ Pioneer } \\
\hline $\mathrm{S} 2$ & 64.5 & 83.8 & 151.7 & 128.9 & 83.8 & 53.6 & 35.4 & 6.0 & 11.3 & 24.2 \\
\hline $\mathrm{S} 1$ & 60.3 & 78.4 & 152.2 & 129.4 & 78.4 & 50.1 & 47.0 & 7.9 & 15.8 & 31.2 \\
\hline $\mathrm{S} 2$ & 63.1 & 82.0 & 149.3 & 126.9 & 82.0 & 52.5 & 44.3 & 7.0 & 13.6 & 30.7 \\
\hline S3 & 54.9 & 71.4 & 132.7 & 112.8 & 71.4 & 45.7 & 41.1 & 9.6 & 16.5 & 24.6 \\
\hline \multicolumn{11}{|l|}{ Timothy } \\
\hline \multicolumn{11}{|l|}{ Climax } \\
\hline $\mathrm{S} 1$ & 46.2 & 60.1 & 69.5 & 59.1 & 58.1 & 37.2 & 58.8 & 21.9 & 28.1 & 30.7 \\
\hline $\mathrm{S} 2$ & 46.0 & 60.0 & 72.1 & 61.3 & 59.9 & 38.3 & 52.9 & 25.4 & 31.6 & 21.3 \\
\hline \multicolumn{11}{|l|}{ Joliette } \\
\hline SEM & 1.75 & 2.27 & 4.57 & 3.88 & 3.39 & 2.17 & 2.19 & 3.00 & 1.48 & 1.89 \\
\hline \multicolumn{11}{|l|}{ Treatment contrasts $^{2}$} \\
\hline Alfalfa vs. timothy & $* * *$ & $* * *$ & $* * *$ & $* * *$ & $* * *$ & $* * *$ & $*$ & $* * *$ & $* * *$ & $* * *$ \\
\hline Pioneer vs. Beaver & NS & NS & NS & NS & NS & NS & $\dagger$ & NS & $\dagger$ & NS \\
\hline Climax vs. Joliette & $*$ & $*$ & $* * *$ & $* * *$ & $* * *$ & $* * *$ & $*$ & $* *$ & NS & $*$ \\
\hline \multicolumn{11}{|l|}{ In alfalfa } \\
\hline $\mathrm{S} 1$ vs. $\mathrm{S} 2$ & NS & NS & NS & NS & NS & NS & NS & NS & NS & NS \\
\hline S1 vs. S3 & $*$ & $*$ & $*$ & $*$ & NS & NS & NS & NS & NS & $\dagger$ \\
\hline S2 vs. S3 & $* *$ & $* *$ & NS & NS & NS & NS & NS & NS & * & NS \\
\hline \multicolumn{11}{|l|}{ In timothy } \\
\hline $\mathrm{S} 1$ vs. S2 & NS & NS & NS & NS & NS & NS & $\dagger$ & NS & NS & $* *$ \\
\hline S1 vs. S3 & NS & NS & $\dagger$ & $\dagger$ & $\dagger$ & $\dagger$ & $* *$ & $* *$ & NS & $* *$ \\
\hline S2 vs. S3 & $\dagger$ & $\dagger$ & $\dagger$ & $\dagger$ & $\dagger$ & $\dagger$ & NS & $\dagger$ & NS & NS \\
\hline
\end{tabular}

${ }^{1}$ Stage: $\mathrm{S} 1$ = $1 \mathrm{wk}$ before commercial cut (early bud for alfalfa varieties and joint for timothy varieties); S2 = at commercially cutting stage (late bud for alfalfa varieties and prebloom head for timothy varieties); S3 = 1 wk after commercial cut (early bloom for alfalfa varieties and full head for timothy varieties). MP = metabolizable protein, defined as the true protein that is digested postruminally and the component AA absorbed by the intestine) contributed by 1) ruminally undegraded feed crude protein (RUP ${ }^{\mathrm{NRC}}$ ), 2) ruminally synthesized microbial crude protein $\left(\mathrm{MCP}^{\mathrm{NRC}}\right)$, and 3) endogenous CP $(\mathrm{ECP})$, calculated as: MP = ARUP ${ }^{\mathrm{NRC}}+\mathrm{AMCP}^{\mathrm{NRC}}+\mathrm{AECP}(\mathrm{NRC}, 2001)$. Degraded Protein Balance $^{\mathrm{NRC}}(\mathrm{g} / \mathrm{kg} \mathrm{DM})$ reflecting the difference between the potential microbial protein synthesis based on ruminally degraded feed crude protein $\left(\mathrm{RDP}^{\mathrm{NRC}}\right.$ ) and that based on energy (available TDN) available for microbial fermentation in the rumen, calculated as: RDP 1.18MCP $\mathrm{MDN}_{\mathrm{TDN}}(\mathrm{NRC}, 2001)$.

${ }^{2} \mathrm{NS}=P>0.1 ; \dagger=P<0.10 ; *=P<0.05 ; * *=P<0.01, * * *=P<0.001$

where, $\mathrm{R}^{2}=0.9998, P<0.0001, \mathrm{RSD}=0.71$.

3. $\mathrm{DVE}=1.02( \pm 0.05) \times \mathrm{MP}-10.22( \pm 3.48)$, where, $\mathrm{R}^{2}=0.95, P<0.0001, \mathrm{RSD}=5.04$.

4. Degraded Protein Balance ${ }^{\mathrm{DVE}}=0.95( \pm 0.02) \times$ Degraded Protein Balance ${ }^{\mathrm{NRC}}-1.23( \pm 0.94)$, where, $\mathrm{R}^{2}=0.99, P<0.0001, \mathrm{RSD}=4.10$.

\section{DISCUSSION}

Input data generated by both models (the DVE/OEB system and NRC-2001 model), though of significance in the dairy cows, are best regarded as characteristics of the test materials. The NRC-2001 model is a newly released, revised model for dairy cattle. The principles of the two models for predicting metabolizable protein value are similar. However, some concepts used for calculation of data are different. For example, both models consider endogenous protein; however, the concepts and definitions are different. In the DVE/OEB system (Tamminga et al., 1994), calculation of the DVE value requires a correction for endogenous protein losses in the small intestine, which are affected by undigested DM. According to the DVE/OEB system, $75 \mathrm{~g}$ of absorbed protein per kg undigested DM in fecal excretion is required to compensate for the endogenous losses. In the NRC-2001 model, calculation of the MP value considers rumen endogenous protein passed on to the small intestine. It contributes to the total MP value. The rumen endogenous protein is associated with DM content. However, the NRC-2001 model does consider the endogenous protein losses in the small 
Table 6. Prediction of truly rumen endogenous protein, total metabolizable protein (MP), and degraded protein balance in the small intestine $(\mathrm{g} / \mathrm{kg} \mathrm{DM})$ to dairy cows from alfalfa and timothy using the NRC2001 Dairy model: effect of variety and cutting stage. ${ }^{1}$

\begin{tabular}{lllll}
\hline & \multicolumn{2}{c}{ Endogenous protein } & & \\
\cline { 2 - 3 } Item & ECP & AECP & MP & Degraded protein \\
balance
\end{tabular}

\footnotetext{
${ }^{1}$ Stage: $\mathrm{S} 1$ = 1 wk before commercial cut (early bud for alfalfa varieties and joint for timothy varieties); $\mathrm{S} 2$ = at commercially cutting stage (late bud for alfalfa varieties and prebloom head for timothy varieties); S3 = $1 \mathrm{wk}$ after commercial cut (early bloom for alfalfa varieties and full head for timothy varieties). MP $=$ metabolizable protein, defined as the true protein that is digested postruminally and the component AA absorbed by the intestine) contributed by 1) ruminally undegraded feed crude protein (RUP $\left.{ }^{\mathrm{NRC}}\right), 2$ ) ruminally synthesized microbial crude protein $\left(\mathrm{MCP}^{\mathrm{NRC}}\right.$ ), and 3) endogenous $\mathrm{CP}(\mathrm{ECP})$, calculated as: MP = ARUP ${ }^{\mathrm{NRC}}$ $+\mathrm{AMCP}^{\mathrm{NRC}}+\mathrm{AECP}(\mathrm{NRC}, 2001)$. Degraded protein balance ${ }^{\mathrm{NRC}}$ (g/kg DM) reflecting the difference between the potential microbial protein synthesis based on ruminally degraded feed crude protein $\left(\mathrm{RDP}^{\mathrm{NRC}}\right)$ and that based on energy (available TDN) available for microbial fermentation in the rumen, calculated as: $\mathrm{RDP}-1.18 \mathrm{MCP}_{\mathrm{TDN}}(\mathrm{NRC}, 2001)$.

${ }^{2} \mathrm{NS}=P>0.1 ; \dagger=P<0.10 ; *=P<0.05 ; * *=P<0.01, * * *=P<0.001$.
}

intestine, but it is added to requirements rather than subtracted from supply. This is a big difference.

The difference was also found in predicted ruminally undegraded feed protein between the two models. In the DVE/OEB system (Tamminga et al., 1994), the ruminally undegraded feed protein was calculated as: $1.11 \times \mathrm{CP} \times \% \mathrm{RUP}$. The factor 1.11 represents the regression coefficient of in vivo on in situ degradation data. However, using the NRC-2001 model, the ruminally undegraded feed $\mathrm{CP}$ was calculated as: $\mathrm{CP} \times$ \%RUP. No correction is made for the difference between in vivo and in situ results.

In the prediction of microbial protein supply based on ruminally degraded feed protein, the two models are also different. In the DVE/OEB system (Tamminga et al., 1994), it is assumed that $100 \%$ ruminally degraded feed protein could be potentially converted to microbial protein if enough energy is provided. However, in the NRC-2001 model, it is assumed that only $85 \%$ of ruminally degraded feed protein could be potentially converted to microbial protein.

To calculate truly absorbed protein in the small intestine contributed from the ruminally undegraded feed protein, the two models use different factor parameters. In the DVE/OEB system, the amount of truly absorbed rumen synthesized microbial protein in the small intestine was estimated as: $0.85 \times 0.75 \times$ $\mathrm{MCP}_{\mathrm{FOM}}$. It assumes that true digestibility of micro- 
Table 7. The mean, standard deviation, and the range of the predicted values for potential microbial protein supply based on available energy and ruminally degraded feed protein in alfalfa and timothy, calculated according to the DVE/OEB system and the NRC-2001 model and correlation of the predicted values by the two models. ${ }^{1}$

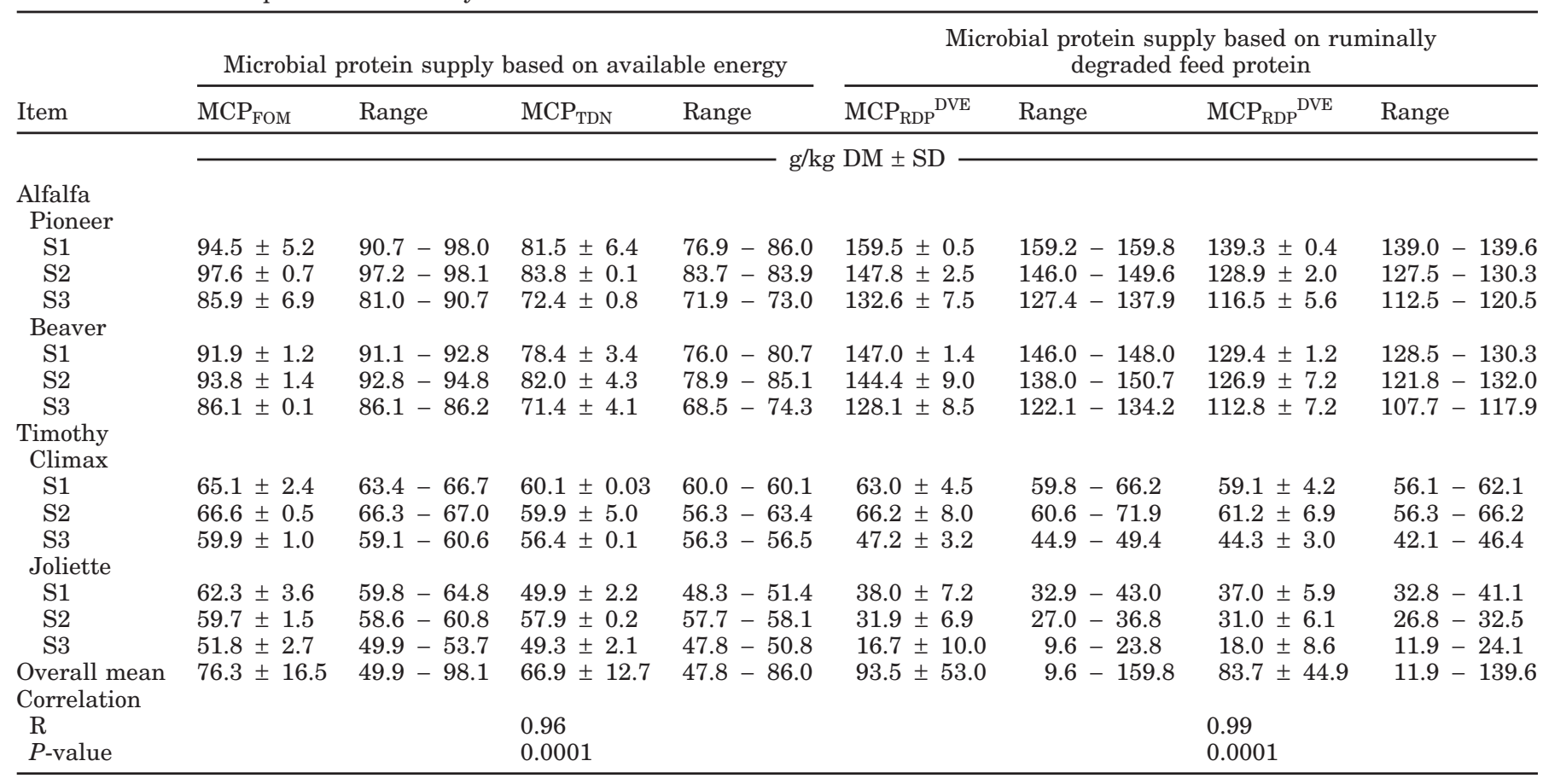

${ }^{1}$ Stage: $\mathrm{S} 1$ = 1 wk before commercial cut (early bud for alfalfa varieties and joint for timothy varieties); $\mathrm{S} 2=$ at commercially cutting stage (late bud for alfalfa varieties and prebloom head for timothy varieties); S3 $=1$ wk after commercial cut (early bloom for alfalfa varieties and full head for timothy varieties). $\mathrm{MCP}_{\mathrm{FOM}}=$ microbial protein supply $(\mathrm{g} / \mathrm{kg} \mathrm{DM})$ based on available energy, calculated as $0.15 \times \mathrm{FOM}$ (DVE/OEB-system: Tamminga et al., 1994). $\mathrm{MCP}_{\mathrm{TDN}}=$ microbial protein supply $(\mathrm{g} / \mathrm{kg} \mathrm{DM})$ based on available energy, calculated as $0.13 \times$ $\mathrm{TDN}_{\mathrm{dis}}(\mathrm{NRC}, 2001) . \mathrm{MCP}_{\mathrm{RDP}} \mathrm{DVE}=$ microbial protein supply $(\mathrm{g} / \mathrm{kg} \mathrm{DM})$ based on rumen undegraded feed protein, calculated as CP $\times(1-$ $1.11 \% R U P / 100)\left(D V E / O E B-s y s t e m:\right.$ Tamminga et al., 1994). $\mathrm{MCP}_{\mathrm{RDP}}{ }^{\mathrm{NRC}}=$ microbial protein supply (g/kg DM) based on rumen undegraded feed protein, calculated as $0.85 \times$ RDP (Tamminga et al., 1994).

bial protein is $85 \%$ (Egan et al., 1985), and $75 \%$ of microbial $\mathrm{N}$ is present in amino acids; the remaining is $\mathrm{N}$ in nucleic acids. In the NRC-2001 model, digestibility and true protein of ruminally synthesized microbial $\mathrm{CP}$ are assumed to be $80 \%$; therefore, the amount of truly absorbed rumen synthesized microbial protein in the small intestine was estimated as: 0.80 $\times 0.80 \times \mathrm{MCP}^{\mathrm{NRC}}$. Although the individual coefficients differ, the net result is essentially the same between the two models $(0.85 \times 0.75)$ vs. $(0.80 \times 0.80)$.

Both models could predict the potential microbial protein synthesized in the rumen based on available energy. The DVE/OEB system uses rumen fermented $\mathrm{OM}$ as energy base to predict microbial protein. However, the NRC-2001 model uses available TDN as its energy base. This is a difference. Each model also uses different factor parameters to calculate microbial protein synthesized in the rumen. In the DVE/OEB system, $150 \mathrm{~g}$ of microbial protein $\mathrm{CP}$ is assumed to be synthesized per $\mathrm{kg}$ fermented OM. But in the NRC2001 model, it is assumed that $130 \mathrm{~g}$ of microbial protein CP is assumed to be synthesized per $\mathrm{kg}$ TDN.
All above individual differences contribute to a difference in prediction of amount of total truly absorbed protein in the small intestine (DVE vs. MP) between the two models. In this study, using the DVE/OEB system, the overall average microbial protein supply based on available energy - rumen fermented OM was $12 \%$ higher, microbial protein supply based on ruminally degraded feed protein was $10 \%$ higher, and the truly absorbed protein in the small intestine was $15 \%$ lower than that predicted by the NRC-2001 model.

However, the correlation of the predicted values from the two models was high (R 0.96 0.99) (Tables 7 and 8). This is due to the fact that the standard deviations and the range of the predicted values from the two models were similar. Both are based on similar principles.

The difference was also found in the prediction of the degraded protein balance, which was $11 \%$ higher based on the data from the NRC-2001 model than in the DVE/OEB system (Tables 3 through 8 ). These differences are due to the factors used in quantifying calculations rather than the difference in principles 
Table 8. The mean, standard deviation, and the range of the predicted values for total truly absorbed protein in the small intestine and degraded protein balance in alfalfa and timothy, calculated according to the DVE/OEB system and the NRC-2001 model and correlation of the predicted values by the two models. ${ }^{1}$

\begin{tabular}{|c|c|c|c|c|c|c|c|c|}
\hline \multirow[b]{2}{*}{ Item } & \multicolumn{4}{|c|}{ Truly absorbed protein in the intestine } & \multicolumn{4}{|c|}{ Degraded protein balance } \\
\hline & DVE & Range & MP & Range & DVE/OEB & Range & NRC-2001 & Range \\
\hline & & & & - g & $\mathrm{DM} \pm \mathrm{SD}$ & & & \\
\hline \multicolumn{9}{|l|}{ Pioneer } \\
\hline S1 & $80.1 \pm 7.9$ & $74.6-85.7$ & $85.4 \pm 6.7$ & $80.7-90.1$ & $65.2 \pm 5.6$ & $61.2-69.1$ & $67.8 \pm 8.0$ & $62.1-73.5$ \\
\hline $\mathrm{S} 2$ & $76.7 \pm 0.2$ & $76.5-76.8$ & $82.2 \pm 0.7$ & $81.7-82.7$ & $50.2 \pm 1.9$ & $48.8-51.5$ & $52.8 \pm 2.5$ & $51.1-54.6$ \\
\hline $\mathrm{S} 2$ & $81.9 \pm 3.7$ & $79.3-84.5$ & $87.6 \pm 6.8$ & $82.8-92.4$ & $50.6 \pm 7.6$ & $45.2-55.9$ & $52.5 \pm 13.6$ & $42.9-62.1$ \\
\hline S3 & $66.1 \pm 3.9$ & $63.3-68.8$ & $74.7 \pm 4.7$ & $71.3-78.2$ & $42.0 \pm 8.6$ & $36.0-48.1$ & $48.5 \pm 3.7$ & $45.9-51.1$ \\
\hline \multicolumn{9}{|l|}{ Timothy } \\
\hline \multicolumn{9}{|l|}{ Climax } \\
\hline $\mathrm{S} 1$ & $59.4 \pm 4.0$ & $56.5-62.2$ & $72.3 \pm 4.1$ & $69.5-75.2$ & $-2.0 \pm 2.2$ & $-3.6--0.5$ & $-1.4 \pm 5.0$ & $-5.0-2.1$ \\
\hline S2 & $46.9 \pm 4.4$ & $43.7-50.0$ & $64.0 \pm 6.7$ & $59.3-68.8$ & $-0.4 \pm 7.5$ & $-5.7-4.9$ & $1.4 \pm 2.2$ & $-0.13-3.0$ \\
\hline Overall mean & $57.1 \pm 21.8$ & $14.9-85.7$ & $65.7 \pm 20.8$ & $19.6-92.4$ & $17.3 \pm 37.0$ & $-40.3-69.1$ & $19.5 \pm 38.7$ & $-42.4-73.5$ \\
\hline \multicolumn{9}{|l|}{ Correlation } \\
\hline $\mathrm{R}$ & & & 0.97 & & & & 0.99 & \\
\hline$P$-value & & & 0.001 & & & & 0.0001 & \\
\hline
\end{tabular}

${ }^{1}$ Stage: $\mathrm{S} 1$ = 1 wk before commercial cut (early bud for alfalfa varieties and joint for timothy varieties); S2 = at commercially cutting stage (late bud for alfalfa varieties and prebloom head for timothy varieties); S3 $=1$ wk after commercial cut (early bloom for alfalfa varieties and full head for timothy varieties). DVE = truly digested and absorbed protein in the small intestine (g/kg DM), contributed by 1 ) feed protein escaping rumen degradation $\left.\left(\mathrm{RUP}^{\mathrm{DVE}}\right), 2\right)$ microbial protein synthesized in the rumen $\left(\mathrm{MCP}_{\mathrm{FOM}}\right)$, and 3$)$ a correction for endogenous protein losses in the digestive tract $\left(\mathrm{ENDP}^{\mathrm{DEV}}\right)$, caluclated as: DVE $=\mathrm{ARUP}^{\mathrm{DVE}} \div \mathrm{AMCP}^{\mathrm{DVE}}-\mathrm{ENDP}^{\mathrm{DEV}}(\mathrm{DVE} / \mathrm{OEB}$ system: Tamminga et al., 1994). MP = metabolizable protein, defined as the true protein that is digested postruminally and the component AA absorbed by the intestine, contributed by 1 ) ruminally undegraded feed crude protein $\left.\left(\mathrm{RUP}^{\mathrm{NRC}}\right), 2\right)$ ruminally synthesized microbial crude protein $\left(\mathrm{MCP}^{\mathrm{NRC}}\right)$, and 3) endogenous crude protein $\left(\mathrm{ECP}^{\mathrm{NRC}}\right)$, calculated as: $\mathrm{MP}=\mathrm{ARUP}^{\mathrm{NRC}}+\mathrm{AMCP}^{\mathrm{NRC}}+\mathrm{AECP}^{\mathrm{NRC}}$ (NRC, 2001). Degraded protein balance $(\mathrm{g} / \mathrm{kg} \mathrm{DM})$ in the DVE/OEB model reflecting the difference between the potential microbial protein synthesis based on degraded feed crude protein and that based on energy available for microbial fermentation in the rumen, calculated as: $\mathrm{RDP}^{\mathrm{DVE}}-\mathrm{MCP}_{\mathrm{FOM}}(\mathrm{DVE} / \mathrm{OEB}-\mathrm{system}$ : Tamminga et al., 1994). Degraded protein balance ( $/ \mathrm{kg} \mathrm{DM}$ ) in the NRC-2001 model reflecting the difference between the potential microbial protein synthesis based on ruminally degraded feed crude protein (RDP ${ }^{\mathrm{NRC}}$ ) and that based on energy (discounted TDN) available for microbial fermentation in the rumen, calculated as: $\mathrm{RDP}^{\mathrm{NRC}}-1.18 \mathrm{MCP}_{\mathrm{TDN}}$ (based on the data from the NRC-2001 model).

upon which the two systems are based. The most important outputs (net results), the DVE in the DVE/ OEB system vs. the MP in the NRC-2001 model, were a $8.6 \mathrm{~g} / \mathrm{kg}$ DM difference, on average (Tables 7 and 8).

Both the DVE/OEB model and the NRC-2001 model are deterministic (not stochastic) and empirical and are based on several assumptions. For example, in the DVE/OEB model, $150 \mathrm{~g}$ of microbial protein is assumed to be synthesized per $\mathrm{kg}$ rumen fermented OM. In the NRC-2001 model, $130 \mathrm{~g}$ of microbial protein is assumed to be synthesized per $\mathrm{kg}$ TDN. Therefore, potential nutrient supply, such as microbial CP supply based on nutrient intake in each group, does not vary a great deal in either model. This is in contrast to microbial CP supply based on total purine derivative excretion (Yu et al., 2001) or based on in vivo measurement (De Boever et al., 1998). This is because in vivo or purine derivative methods are relative measures of the real microbial CP production. They are affected by several factors, such as ruminal $\mathrm{pH}$ and ruminal turnover rate and by individual animal variation (Hoover and Stokes, 1991; Moscardini et al., 1998), not only nutrient intake.

Protein evaluation results by both the DVE/OEB system and the NRC-2001 model indicated that the alfalfa varieties had no effect, but timothy varieties had a large impact on the potential nutrient supply to dairy cows. In this experiment, with increasing stage of cutting, the potential nutritive values were reduced in both forages. However, the sensitivity of the two models to detect the difference between stages was different. For example, using the DVE/OEB system, truly absorbed intestinal protein DVE values between stages in alfalfa were detected to be significantly different (Tables 3 and 4). However, using the NRC-2001 model, truly absorbed intestinal protein MP values between stages in alfalfa were not different (Tables 5 and 6). 
The DVE/OEB system introduced a new concept the role of energy balance in protein supply: the Degraded Protein Balance. It can also be calculated based on data from the NRC-2001 model. The Degraded Protein Balance (in the DVE/OEB system) shows the (im)balance between microbial protein synthesis from available rumen degradable $\mathrm{CP}$ and potential energy from anaerobic fermentation in the rumen. When the Degraded Protein Balance in a ration is positive, it indicates the potential N-loss from the rumen. When negative, microbial protein synthesis is predicted to be impaired because of a potential shortage of $\mathrm{N}$ in the rumen. The optimum degraded protein balance value in a ration is, therefore, zero or slightly above (Tamminga et al., 1994). Both models detected that alfalfa had a positive degraded protein balance, indicating a potential imbalance between feed $\mathrm{N}$ degradation and utilization if alfalfa is used alone. Timothy had a negative degraded protein balance, indicating a potential N shortage. However, the amount of predicted $\mathrm{N}$ losses in alfalfa or $\mathrm{N}$ shortages in timothy in terms of optimum rumen fermentation were different between the two models. Using the data from the NRC2001 model resulted in higher degraded protein balances.

All of the results reported here were outputs from the models with inputs based on in vitro and in situ. The challenge is to apply the predictions and evaluate them in an animal experiment between the two models. The number of such studies is limited, particularly using the DVE/OEB system. Part of the reason is that information on DVE and the Degraded Protein Balance values of each feedstuff, or data from which these are derived is limited.

\section{CONCLUSIONS}

The predicted protein values from the DVE/OEB system and the NRC-2001 model had significant correlations with high $\mathrm{R}$ values. However, using the DVE/ OEB system, the microbial protein supply based on available energy was $12 \%$ higher, the Degraded Protein Balance was $11 \%$ lower, and the total truly absorbed protein in the small intestine was $15 \%$ lower than that predicted using the NRC-2001 model. These differences are due to the fact that some of the factors used in quantifying calculations differ considerably, although the principles of these two systems are similar.

The DVE/OEB and the NRC-2001 model are systems, including both supply and requirement models. The requirement models between the DVE/OEB system and the NRC-2001 model are also different. The nutrient balance (model requirement minus model supply) between two models will be investigated.

\section{ACKNOWLEDGMENTS}

The authors thank Elcan Forage, Inc. (Saskatchewan, Canada) for providing samples, the technical staff in Department of Animal and Poultry Science, University of Saskatchewan (Canada) for helpful assistance and chemical analysis, Saskatchewan Agricultural Development Fund (ADF) and Natural Sciences and Engineering Research Council of Canada (NSERC) for financial support.

\section{REFERENCES}

AOAC. 1990. Association of Official Analytical Chemists. Official Methods of Analysis. 15th ed. Arlington, VA.

ARC. 1984. Page 45 in The Nutrient Requirement of Ruminant Livestock. Suppl. No. 1. Commonwealth Agricultural Bureaux, Slough, England.

Canadian Council on Animal Care. 1993. Guide to the Care and Use of Experimental Animals. Vol.1, 2nd ed. CCAC, Ottawa, ON.

CVB. Centraal Veevoeder Bureau. 1996. Voorlopig protocol voor in sacco pensincubatie voor het meten van eiwitbestendigheid, 14 November.

De Boever, J. L., N. Iantcheva, B. G. Cottyn, S. De Campeneere, L. O. Fiems, and CH. V. Boucque. 1998. Microbial protein synthesis in growing-finishing bulls estimated from the urinary excretion of purine derivatives. Anim. Feed Sci. Technol. 75:93-109.

Egan, A. R., K. Koda, and K. Barady. 1985. Regulation of N metabolism and recycling. In: Control of digestion and metabolism in ruminants. Pages 146-153 in Proc. 6th International Symposium on Ruminant Physiology. Butterworths, London.

Hoover, W. H., and S. R. Stokes. 1991. Balancing carbohydrates and proteins for optimum rumen microbial yield. J. Dairy Sci. 74:3630-3644.

INRA. 1978. Alimentation des ruminants. Page 597 in Inst. National de la Rech. Agron. Versailles.

Licitra, G., T. M. Hernandezb, and P. J. Van Soest. 1996. Standardization of procedures for nitrogen fractionation of ruminant feeds. Anim. Feed Sci. Technol. 57:347-358.

Maden, J. 1985. The basis for the proposed Nordic protein evaluation system for ruminants. The AAT-PBV system. Acta. Agri. Scand. (Suppl.) 25:9-20.

Markert, J. D., and D. A. Christensen. 2002. A comparison of the nutritional characteristics of two cultivars of alfalfa and timothy at three stages of maturity. Thesis, Dept. Animal and Poultry Science, Univ. Saskatchewan, Canada.

Marten, G. C., and R. F. Barnes. 1980. Prediction of energy digestibility of forage with in vitro rumen fermentation and fungal enzyme systems. Pages $61-71$ in Proc. Int. Workshop on Standardization, Analytical Methodology for Feeds. W. J. Pigden, G. C. Balch, and M. Graham, ed. Ottawa, Canada.

McKinnon, J. J., J. A. Olubobokun, A. Mustafa, R. D. H. Cohen, and D. A. Christensen. 1995. Influence of dry heat treatment of canola meal on site and extent of nutrient disappearance in ruminant. Anim. Feed Sci. Technol. 56:243-252.

Moscardini, S., T. C. Wright, P. H. Luimes, B. W. McBride, and P. Susmel. 1998. Effects of rumen-undegradable protein and feed intake on purine derivative and urea nitrogen: Comparision with predictions from the Cornell Net Carbohydrate and Protein System. J. Dairy Sci. 81:2421-2429.

Muia, J. M. K., S. Tamminga, P. N. Mbugua, and J. N. Kariuki. 2001. Rumen degradation and estimation of microbial protein yield and intestinal digestion of napier grass (Pennisetum purpureum) and various concentrates. Anim. Feed Sci. Technol. 93:177-192. 
NKJ-NJF. 1985. Introduction of the Nordic protein evaluation system for ruminants into practice and future research requirements. Proposals by the NKJ-NJF protein group. Acta Agric. Scand. 25 (Suppl.):216-220.

NRC. 1985. Ruminant nitrogen usage. Page 138 in National Academy Press. Washington DC.

NRC. 2001. Nutrient requirement of dairy cattle. 7th rev. ed. National Research Council, Washington, DC.: National Academy Press.

Ørskov, E. R., and I. McDonald. 1979. The estimation of protein degradability in the rumen from incubation measurements weighted according to the rate of passage. J. Agric. Sci., (Cambridge) 92:499-503.

Robinson, P. H., J. G. Fadel, and S. Tamminga. 1986. Evaluation of mathematical models to describe neutral detergent residue in terms of its susceptibility to degradation in the rumen. Anim. Feed Sci. Technol. 15:249-271.

SAS. 1991. SAS/STAT User's Guide (Release 6). SAS Inst., Inc., Cary, NC.

Sniffen, C. J., J. D. O'Connor, P. J. Van Soest, D. G. Fox, and J. B. Russell. 1992. A net carbohydrate and protein system for evaluating cattle diets: II. Carbohydrate and protein availability. J. Anim. Sci. 70:3562-3577.

Tamminga, S., A. M. van Vuuren, C. J. van der Koelen, R. S. Ketelaar, and P. L. van der Togt. 1990. Ruminal behavior of structural carbohydrates, nonstructural carbohydrates, and crude protein from concentrate ingredients in dairy cows. Neth. J. Agric. Sci. 38:513-526.

Tamminga, S., W. M. Van Straalen, A. P. J. Subnel, R. G. M. Meijer, A. Steg, C. J. G. Wever, and M. C. Block. 1994. The Dutch Protein Evaluation System: The DVE/OEB-system. Livest. Prod. Sci. 40:139-155.

Van Soest, P. J., J. B. Robertson, and B. A. Lewis. 1991. Symposium: Carbohydrate methodology, metabolism and nutritional implications in dairy cattle. Methods for dietary fiber, neutral deter- gent fiber, and nonstarch polysaccharides in relation to animal nutrition. J. Dairy Sci. 74:3583-3597.

Varhegyi, J., J. Schmidt, E. Cenkvari, J. Varhegyi. 1998. Comparison of the new Hungarian protein evaluation system for ruminants with foreign systems. Allattenyesztes es Takarmanyozas. 47:239-246.

Vérité, R., and Y. Geay. 1987. Evaluation and implementation of the PDI system in France. Pages 249-261 in Feed valuation and protein requirement systems for ruminants. R. Jarrige, and G. Aldeirman, ed. ECSC-EEC-EAEC. Brussels.

Weiss, W. P., H. R. Conrad, and N. R. S. Pierre. 1992. A theoreticallybased model for predicting total digestible nutrient values of forages and concentrates. Anim. Feed Sci. Technol. 39:95-110.

Yu, P., A. R. Egan, and B. J. Leury. 1999. Protein evaluation of dry roasted whole faba bean and lupin seeds by the new Dutch protein evaluation system: The DVE/OEB system. Asian-Austr. J. Anim Sci. 12:871-880

Yu, P., J. O. Goelema, S. Tamminga. 2000. Determination of optimal conditions of pressure toasting on horse beans for dairy feed industry, by the DVE/OEB model. Anim. Feed Sci. Technol. 86:165-176.

Yu, P., L. Boon-ek, B. J. Leury, and A. R. Egan. 2001. Effect of dietary protein variation in terms of net truly digested intestinal protein (DVE) and rumen degraded protein balance (OEB) on the concentrations and excretion of urinary creatinine, purine derivatives, and microbial $\mathrm{N}$ supply in sheep: Comparison with the prediction from the DVE/OEB model. Anim. Feed Sci. Technol. 93:71-91

Yu, P., D. A. Christensen, J. J. McKinnon, and J. Markert. 2002a. Effect of variety and maturity stage on chemical composition, carbohydrate, and protein subfractions, in vitro rumen degradability and energy values of timothy and alfalfa. Can. J. Anim. Sci. 83: (In press).

Yu, P., J. O. Goelema, B. J. Leury, S. Tamminga, and A. R. Egan. $2002 \mathrm{~b}$. An analysis of the nutritive value of heat processed legume seeds for animal production using the DVE/OEB model: A review. Anim. Feed Sci. Technol. 99:141-176. 